DOI https://doi.org/10.36059/978-966-397-242-8-6

Nasakina S. V.,

Candidate of Philological Sciences, Associate Professor, Head of the Ukrainian and Foreign Languages Department

Odesa State Agrarian University, Odesa

\title{
PECULIARITIES OF THE ENGLISH-LANGUGE BOOKS ADVERTISING ONLINE
}

Summary. The article dwells on the problem of online books advertising texts. Book advertising texts implement the following tasks: to attract readers'attention; to interest the recipients and encourage them to further reading; arouse the desire to have an advertised book; induce to action. Attention is paid to the description of linguistic features of book advertising texts. The purpose of the article is the analysis of the book advertising texts. The object of the study is on-line book advertising texts. The subject of the study is linguistic and onomastics features of online book advertising texts. The purpose determines the choice of methods in our study: general scientific methods of systematization were used. The descriptive method and the method of analysis and synthesis were used in the work as well. Each type of linguistic device and proper name were illustrated by a concrete example of book advertising text. Summing up the above, we can emphasize that for the first time an analysis of online book advertising texts was carried out in the view of rhetoric and onomastics.

\section{Introduction}

Literature has always occupied an important place in human life, sometimes the book could be one of the reasons for the value reorientation of society. Nowadays the modern book advertising is like a mediator between the author and the audience and the purpose of the book advertising is to transmit information to potential buyers and readers about a new book, a new author and new ideas. It is a well known fact that the advertising texts are constantly being enriched by new elements and by new genres. In addition, great opportunities for persuading the buyer to choose the book online provide genre features of language material, so our study needs to search the patterns of compositional design of books advertising texts. The effectiveness of a 
book depends on the genre specifics, figurative means of language, and book advertising. It has been offered some language techniques used in the English advertising texts. This paper researched the rhetoric and onomastics means of persuasion in the online book advertising texts. In the present paper, 1000 book advertising texts extracted from the sites for readers were analyzed. It is highlighted some of the peculiarities of book advertising texts. Examples are adduced to show the peculiarities of online advertising. Also, this study attempts to shed more light on the special functions of the proper names in books advertising texts that help to attract readers' attention. The scientific novelty of the work lies in the fact that it is for the first time that a comprehensive analysis of English proper names in the online book advertising texts has been performed.

Although the topic of the advertisement has been exploited for a long period, there is still new light that can be thrown on this, such as peculiarities of books advertising texts from rhetoric and onomastics standpoints. Even though advertising, as one of the brightest phenomena of our time, occupies a special place in the life of the 21-st century person, very little research has been carried out on modern book advertising on the Internet. To overcome this problem, in this paper we demonstrate the wide range the lexical, morphological, and stylistic devices used in modern books advertising texts. The present study that has been made has focused on book advertisements in the English language.

Advertising has been existing in written and oral forms throughout the whole of mankind's life. Tungate [33, p. 10] claims that "advertising has been around for as long as there have been goods to sell and a medium to talk them up". Books advertising has been evolving and transforming for centuries. For instance, the Roman booksellers in ancient times used to placard their shops with the titles of the new books they had for sale. It is thought that book lists were the old, traditional form of literary advertising and they exist in our times as well. According to Sivulka, "in 1625, the first newspaper advertisement published in English appeared on the back page of a newsbook; it also promoted a book" [30, p. 6].

On the one hand, nowadays book advertising can be seen in the printed booklets in the bookshops or on special websites, but they are rarely presented on the billboards, in the newspapers and TV. On the other hand, now we are witnessing the development of new forms and genres of book advertising on social networks. Besides, high competition between booksellers makes the advertising texts creators use different 
language means in order to promote their products via the Internet. Book advertising online is the new form of advertising that appeared in the 20th century but it has a lot of similar features with printed book advertising structure and the same methods and forms of persuasion are being used.

Because of advertising is a complex, many-sided phenomenon, it has been receiving considerable attention from many researchers $[2 ; 4 ; 5$; $9 ; 12 ; 14 ; 16 ; 20 ; 25 ; 28 ; 32 ; 33]$. Despite the advertising studies involving an interdisciplinary approach, the language direction is dominant. Scholars are concern with gender, structure, and stylistic, cognitive, sociolinguistic, cross-cultural, pragmatic, and other aspects of advertising. It is a well known fact that the modern advertising texts in the digital era can be often seen on almost all websites.

The material for the paper was taken from websites for books readers such as https://manybooks.net/, https://www.goodreads.com, and https://www.amazon.com, which served annotations of books. These sites are characterized by the stable structure of annotations. In the present article, we consider these books' annotations as advertising texts because they have the same structure and similar objectives.

The research method, which includes two stages, has been presented. The first stage consisted of material collection, the observation of certain morphological, lexical, and syntactical units' use. 1000 books advertising texts were selected using the representative sampling method. The second stage consisted of the description and systematization of the data obtained using particular methods. The descriptive method was used in the paper for inventory and taxonomy of the studied units and constructions.

\section{The structure of books advertising texts}

In one of the first books with tips for creating effective advertising, Aizenstein [1, p.2] stated that in order to persuade the buyers to buy the advertised product, it is necessary, first of all, "to attract readers' attention". That's why the effectiveness of any advertising text is largely determined both by the design of the text material and the inclusion of special lexical units. The well-known rule of advertising was reflected in the AIDA concept, which is "getting attention, holding interest, arousing desire, and obtaining action "[26, p. 491]. This formula presents the action plan for the advertising creators. Both printed advertising and online advertising are a combination of the verbal component and the non- 
verbal elements, they help to create a whole image of the advertised product, but in this paper, we do not research the non-verbal elements.

The discussion will be easier if we have some technical terms to use. First, we need a term for advertising. Some authors have suggested that "advertising is a paid, nonpersonal communication about an organization and its products and services that are transmitted to a target audience through mass media such as television, radio, newspapers, magazines, direct mail, outdoor displays, or mass-transit vehicles"[23, p. 3]. It is worth mentioning that because of the lack of a unified approach both to the definition of advertising and the definition of the advertising text, there is not generally accepted opinion on the structure and number of components in the advertising text [11, p. 51-58; 20, p. 208; 29, p. 141; 31, p. 212]. On the one hand, Arens [9, p. 380] defines the following key format elements in print advertising as "the visual(s), headlines, subheads, body copy, slogans, seals, logos, and signatures". On the other hand, Ward [34, p. 12] claims that "a copywriter may often need only two elements of the complete advertisements" and they are "the headlines and the illustrations" [13, p. 12].

As for the advertising text, the literature review shows that "advertising texts are seen as potentially involving complex notions of audience, where readers have to work hard to decode messages and understand different address relationships" [18, p. 8]. Furthermore, Quinn $[27$, p. 8] has indicated that "literature and advertising share a common purpose, to have its audiences engage in the Willing Suspension of Disbelief" [27, p. 8]. In the light of these statements, we suggest that the online book advertising can be considered as the system including book annotation and readers' reviews that has such components of books advertising text as the headline, which includes the headline, the author's name, or sometimes the illustrator (editor) name, the subhead, the main advertising text (or the body text), the echo-phrase, the product details.

Each element of the advertising text has certain functions: the headline and the subhead should catch the attention of the readers and interest them enough so that they read the main advertising text. The task of the main advertising text is to call the desire to purchase an advertised product or service. The goal of the echo phrase is to persuade the readership to buy the product. Product details usually include the information about the publisher, the language of the book, series, paperback, customer reviews, product dimensions and shipping weight, and sometimes the author's website, book price information. Readers' 
reviews are used in order to attract the attention of the addressee because they create the impression that a certain book is being read by many people. Composite tissue of book advertising text can be represented with more detailed distribution, but the proposed structure, in our opinion, most fully shows the functional purpose of online book advertising. It should be noted that in some cases, the number of components may be different, but, in our opinion, the necessary elements for books advertising texts are the headline, the main advertising text, and the product details, for example,

(1) Beyond the Abyss by Melissa Ojeda (Author), Mollie Heiser (Illustrator)

\section{Promise me you'll find happiness.}

The last words of the dead haunt every step of Bree Booker's life. The only motivation needed for every coin she saves for a one-way trip out of Galegash, a city overflowing with the hopeless. Bree knows she can find happiness in the countryside, to escape from the streets where her next meal was only a dumpster away. Yet, Bree did not expect for the gods themselves to yank the world from beneath her feet. Steeped in centuries long conflict, the city of Galegash isn't what it seems, and a certain feline will prove it.

From a bustling city to a barren wasteland, join Bree in her mindblowing adventure as she discovers what it means to be a soul carrier! Get your box set now with just one click!

In the above-mentioned example, the headline consists of the book's title, the author's name, and the illustrator's name. Generally, the readers choose what they want to read and there are headlines targeted at them. Linguistically speaking, the headline is an obligatory element of any advertising texts.

The subhead is the first sentence after the headline and it expresses the idea of the advertised book. The main advertising text follows after the subhead, and it is usually presented in the form of a summary for the advertised book. The echo-phrase is the effective conclusion of advertising content that both intrigues the readers and suggests buying the book. The main advertising text is usually followed by the echo-phrase. The abovementioned example aims to inform the readership about the idea and the main characters of the advertised book. It must be added that in the analyzed advertising texts there were examples, where one or more advertising elements were missing and in such cases, the functions of the missing structures are compensated by the remaining elements. 
Let us consider the main components of the book advertising text in detail. Much depends on the headline, the purpose of which is to attract readers' attention. The headline serves as a kind of information sign and it helps the readers to determine their choice. For example, the title "When We Left Cuba" prompts the reader that the book is dealt with past events in $C u b a$, and the place name Cuba plays the role of the keyword, attracting the attention of those who are interested in this country. Sometimes the subhead in the book advertising text can consist of series of sentences, the purpose of which is to generate interest in the book, for example,

(2) Inspector Hobbes and the Curse by Wilkie Martin(Author)

Dead sheep. Massive cats. A superhuman detective's sidekick has no clue...

The subhead in the above-mentioned example includes elliptical and unfinished sentences that help to intrigue the reader to discover the unknown information. It is often used questions in the subhead in order to intrigue the auditory and attract readers' attention to the book, for example,

(3) Four winds of love by Danni Caspi

Do you really know your parents? Their loves? Their lives? Their secrets?

Can a child ever recover lost memories and finally know the truth about his parents? This story begins in Paris in the thirties and ends in Israel in the nineties. It is told through four voices, whose lives and loves intertwine through a complex of feelings, secrets, and loyalties. But mostly, it is a novel about a unique woman, about desertions, loneliness, acceptance and forgiving. With exceptional sensitivity this family story unfolds, with heroes whose pain, joy, vulnerability, and vitality blend with moving historical events to create a tantalizing evocation of the power of the imagination to remember and heal what the heart has been striving to forget.

Scroll up now to get your copy of Four Winds of Love!

The title (or the subhead) is usually followed by the main advertising text, and, as a rule, it deals with the plot of the book, the main characters are presented in the main advertising text as well. For example,

(4) The Munich Girl by Phyllis Edgerly Ring (Author)

Anna Dahlberg grew up eating dinner under her father's war - trophy portrait of Eva Braun. Fifty years after the war, she discovers what he never did - that her mother and Hitler's mistress were friends. The secret surfaces with a mysterious monogrammed handkerchief, and a man, Hannes Ritter, whose Third Reich family history is entwined with Anna's. Plunged into the world of the "ordinary" Munich girl who was her mother's confidante - and a tyrant's lover - Anna finds her every belief about right 
and wrong challenged. With Hannes's help, she retraces the path of two women who met as teenagers, shared a friendship that spanned the years that Eva Braun was Hitler's mistress, yet never knew that the men they loved had opposing ambitions. Eva's story reveals that she never joined the Nazi party, had Jewish friends, and was credited at the Nuremberg Trials with saving 35,000 Allied lives. As Anna's journey leads back through the treacherous years in wartime Germany, it uncovers long-buried secrets and unknown reaches of her heart to reveal the enduring power of love in the legacies that always outlast war.

Having read the above-mentioned example, we can see both onomastics and linguistics peculiarities, which will be considered in detail below. First of all, we see personal names Anna Dahlberg, Hannes Ritter, Eva Braun, and Hitler, secondly, place names Germany, Nuremberg, and Munich, thirdly, the ergonyms the Nazi party and the Third Reich. Besides, the repeated lexical units war and love used in the example could attract readers' attention and help to create the impression about the book. The above-mentioned example seems to prove the fact that books advertising texts can fulfill both informational and educational functions because we can see the famous historical figures and geographical names which could be associated with certain historical events.

Sometimes the function of the echo-phrase (final part) of the book advertising text is performed by the questions or calling to buy the book. It is implemented the motivation to action through imperatives, interrogative or exclamatory constructions, for example,

(5) Scroll Up and Grab Your Copy Today!

(6) What are you waiting for? Buy this book today before this timeline is altered and life as we know it ceases to exist.

(7) If you enjoy paranormal thrillers doused in the historical legends of the Vatican and Knights Templar, then this book is for you.

Readers' reviews or comments are also the important elements of online book advertising, they can include opinions of the other authors, for example,

(8)An explosive and visceral debut with the most terrifying of killers. Wes Markin is a new name to watch out for in crime fiction, and I can't wait to see more of Detective Yorke.Bestselling Crime Author Stephen Booth

(9) A pool of blood, an abduction, swirling blizzards, a haunting mystery, yes, Wes Markin's One Last Prayer for the Rays has all the 
makings of an absorbing thriller. I recommend that you give it a go.' Bestselling Author Alan Gibbons

Besides, the readers have the opportunity to evaluate the book in the online rating, for example,

(10) Jeez Louise, the opener hit bull's eye straight away and nothing could stop mefrom being dragged into the story, Els, B for Bookreview, 5 stars

(11) A WOW evoking opening and keeps the wows coming throughout. Shocking and at times disturbing, this is an intense, disconcerting and gripping tale. Bookworms Corner Blog Spot, 5 stars

All these elements of the book advertising are specific for online advertising and they help to attract readers' attention to the book. The task of advertising is to direct consumer behavior to the purchase of the good. To increase the impact of advertising both persuasion and suggestion methods are used. As Arens [9, p. 346] states "rational appeals are directed at the consumer's practical, functional need for the product or service; emotional appeals target the consumer's psychological, social, or symbolic needs". The above-mentioned examples show that expressions (4) - (10) are aimed at the readers' emotions. The example (6) is made in the form of the conditional sentence and it is closer to the rational appeal because logical arguments are used.

So, the online book advertising text is a verbal component of advertising with pragmatic, informational, and educational purposes, characterized by coherence, integrity, presence of certain structural components as the headline, the subhead, the main advertising text, the echo-phrase, the product details, and the readers' reviews or comments. It must be added that book advertising online may often contain the readers' reviews or comments which is specific for online books advertising. Both the emotional component and rational arguments of the advertising are very important for drawing attention to the book. The product details present neutral information but readers' reviews could impact the readers' emotions. Besides, in addition to informational function, the book advertising texts often implement a cultural and educational function.

\section{Linguistic techniques in the books advertising texts}

The methods of techniques and forms of persuasion were studied in the past and are studied at present. The research of the influence of the words occupied a sufficient place in the teachings of the philosophers of ancient 
Greece. The Sophists Gorgias (483-375 BC), Lysias (459-380 BC), Protagoras (490-420 BC) laid the foundations theory of eloquence. Aristotle described the methods of influence in the speech that were used by the Sophists in his work "On Sophistical Refutations". Modern advertising can be considered as one of the areas of using speech influence.

Most modern researchers of speech influence proceed from the fact that the choice of an element of advertising texts can have a certain motivation. First, the language of book advertising texts is characterized by expressiveness, appreciation, and emotional coloring. Second, the pragmatic function is considered one of the main in advertising texts. Advertising professionals have known for a long time that there are certain methods that are very effective in helping to influence people. Linguistic and onomastic techniques serve the aims of any advertising. Beasley R. and Danesi M. [10, p. 113] state that "the use of figurative language is a basic verbal technique for generating verbal textuality". Most of the words in book advertising texts should involve the audience in the reading. Scientists divide rhetoric devices into phonological, morphological, lexical, syntactical levels. Briefly, we shall be able to show how these devices are used on each level in book advertising texts.

At the phonological level, it was allocated alliteration, assonance, rhyme, and rhythm in books advertising texts. Alliteration and assonance play the role of the magnifier to the books advertising texts. According to Cuddon [15, p. 23], "alliteration is a figure of speech, in which consonants, especially at the beginning of words or stressed syllables, are repeated, for example:

\section{(12) Courting Innocence by Kimberley Dean Her big brother's best friend}

(13) The Lighthouse by Jessie Newton

Sisterhood, safety, and secrets-it all happens at the lighthouse on Five Island Cove

(14) Area Zero by William Bowden

Area Zero is a zany, fast-paced thriller accelerating to a breakneck ending that will leave you breathless. Buy Area Zero today and watch Nathan's encounter with the good, the bad, and the downright dysfunctional.

The alliteration and the assonance enhance the keywords and help to strengthen the meaning of the second words. The assonance is considered as the "repetition of similar vowel sounds, usually close together, to achieve a particular effect of euphony" $[15,58]$ in the stressed 
syllables. The example of the assonance is presented more rarely than alliteration, and it is used with alliteration for expressiveness and rhythmical effect, for example,

\section{(15) Just Deserts by Jinx Schwartz}

Hetta Coffey is a sassy Texan with a snazzy yacht and she's not afraid to use it!

The repetition of the same or similar sound combinations and rhythm is a powerful means of language influence that attract readers' attention to the advertising, and these extracts are easily remembered, for example,

(16) His Many Demands by Ali Parker

My Needs. My Demands. Your Pleasure. You're Welcome.

In the above- mentioned example, we can observe rhythmical sentences. Besides, there is both alliteration (the repetition of phoneme $m$ ) and assonance (the repetition of phonemes $y, e$ ). In the analyzed book advertising texts, cases of using rhymes were identified, but they are few.

At the morphological level, the expressiveness of advertising is achieved by repeating the same root morpheme, prefixes or/and suffixes in different words (i.e. by using an abbreviation, negative prefixes), by using occasional words (i.e. created for one occasion only). For example,

(17) Two Assassinations That Appear To Be Linked by J.C. Fields

He suspects the assassinations are related and calls an old friend with the FBI. When FBI profiler Special Agent Sean Kruger arrives at the scene of the second murder, he agrees with Clark but is hesitant to get involved.

The FBI stands for Federal Bureau of Investigation in the USA. Those who have known about this abbreviation do not need to decode it and are in a powerful position above those who do not know. Consequently, some abbreviations can have different associations for readers from different communities and countries, for example:

(18) The Time Traveler by Joe Corso

The Russian President Wants Lucky and the Professor's Secrets

The Arabs want them too. Vladimir Putin is determined to secure the secret recipe that will forever eliminate the need for oil for any type of transportation, forever. Putin has assigned this task to his Head of Security, Oleg Karpov. It is up to Lucky to protect the brilliant, mad scientist and his "magnetic propulsion system", but can he outwit legions of Russian agents? From the KGB headquarters in Moscow to the ghost town of Rhyolite, Lucky, utilizes his time travel ability and races to eradicate assassins, yet increase his wealth at the same time. 
$\boldsymbol{K G} \boldsymbol{B}$, that is, Komitet Gosudarstvennoy Bezopasnosti translated in English as the Committee for State Security, was the main security agency for the Soviet Union from 13 March 1954 until 3 December 1991.Every book advertising text seems to have linguistic units that help to create persuasive text and readers have to decode the message hidden in the book advertising texts. Prefixes repetitions are often used to highlight the key-words. For example,

(19) Home Remedies by Xuan Juliana Wang

Wang's unforgettable characters - with their unusual careers, unconventional sex lives and fantastical technologies...

The implicit information hidden in the words with the prefix un- in the above-mentioned example is to stress the connection between these three words.

At the lexical level, there is a lot of means of expressiveness. Among them, it may be counted epithet, hyperbole, zeugma, oxymoron, metaphor, metonymy, etc. We give some examples below. According to Cuddon [15, p. 282], the epithet is usually "an adjective or phrase expressing some quality or attribute which is characteristic of a person or thing", for example,

(20) Finger of an Angel by Panayotis Cacoyannis Psychological, magical, mad, Lily's journey on a long winding road and beyond.

Epithets in the book advertising texts characterize an object or action and emphasize some quality or property, and sometimes give additional characteristics. It is worth mentioning that advertising creators know that there are certain effective words influence people. They have identified the use of emotional words (very often adjectives) that set the reader to certain emotions. These words are now, for free, magical, unique, mysterious, etc. By the way, anyone studying advertising texts will sooner or later find themselves considering the connection between advertising techniques and manipulation techniques. Ryumshina [7, p. 3] states that "the use of manipulation in advertising raises them to the level of manipulation of public consciousness".

Hyperbole was often found in the books advertising texts. Hyperbole is "a figure of speech which contains an exaggeration for emphasis" [15, p. 406]. It helps to exaggerate one or another property of the object (thing) in the advertising, for example,

(21) Kill 'Em All by Ryan Green

Kill 'Em All is a chilling and gripping account of one of the most brutal and gruesome true crime stories in American history. Ryan Green's riveting 
narrative draws the reader into the real-live horror experienced by the victims and has all the elements of a classic thriller.

Advertising texts are always informative but, besides, they can express emotions with the help of hyperbole in order to influence the readers, for example,

(22) Deadly Lies by Chris Patchell

Hurt Jill Shannon once, shame on you. Hurt Jill Shannon twice, she'll bury you six feet under

Highlighting this or that event, the advertising creator seeks to most successfully convey an important thought for him with the help of expressive meanings like hyperbole which is included in the main content in the form of reinforcing shades, for example,

(23) The Time Traveler and the Professor by Joe Corso

It is up to Lucky to protect the brilliant, mad scientist and his "magnetic propulsion system", but can he outwit legions of Russian agents? From the KGB headquarters in Moscow to the ghost town of Rhyolite, Lucky, utilizes his time travel ability and races to eradicate assassins, yet increase his wealth at the same time.

The expressiveness of such rhetoric tool as zeugma acts as the ability of some constructions to strengthen the pragmatic and proper grammatical information, which are bookmarked in the utterance. According to The Dictionary of Literary Terms and Literary theory, "the zeugma is a figure of speech in which the same word (verb or preposition) is applied to two others in different senses" [15, p. 991]. For example,

(24) A Matter of Trust by Kat Faitour

British financier Bennett Sterling steers his world with iron control and cold determination. Burned by a lover long ago, he guards his heart and business with wary resolve.

The zeugma he guards his heart and business is used for the emotional richness of advertising. Since the main function of the advertising is the function of influence, and the purpose of expressive expressions is to increase the power of the influence, the presence of the rhetoric figures in books advertising texts seems to be obligatory.

Sometimes proverbs are used in the book advertising text, for example,

(25) Area Zero by William Bowden

Nathan is a forensic accountant, and he is to audit said base until every pencil, and every paperclip has been entered into the ledger. There he will be safely out of sight, and out of mind. Welcome to Area Zero, Nathan. 
As noted before, the variety of linguistic means of expressiveness is exhaustible. But the function of influence in books advertising texts is often realized through syntactic expressive means. Among them, we especially highlight the order of words and syntactic parallelism, gradations, and antitheses. Antithesis, that is "fundamentally, contrasting ideas sharpened by the use of opposite or noticeably different meanings" $[15$, p. 46], is widespread in the books advertising texts, for example,

(26) Vampire Moon by Patrick Hogan

Now in Vampire Moon, private investigator Samantha Moon finds herself hunting down a powerful crime lord and protecting an innocent woman from her ruthless ex-husband-all while two very different men vie for her heart.

With the help of antithesis an innocent woman and ruthless exhusband the advertising text presents the main heroes of the book and the reader can at once imagine the idea of the book. Metaphors and metonymy are often included in the book advertising texts. According to Cuddon [15, p. 507], metaphor is "a figure of speech in which one thing is described in terms of another" and metonymy is "a figure of speech in which the name of an attribute or a thing is substituted for the thing itself" $[15$, p. 510]. The next example which is topical in the present times has both metaphor and metonymy:

(27) Panik by Chris Selwyn James

Whatever you do, don't sleep... because it's when you wake up that the Panic comes.

The epidemic starts in Oxford. Yet people are still dying in the night. In this world, Nick peddles powerful sleep-deprivation drugs, while Rosa is locked up in a government "safe house" because they think she is the key to finding a cure. Set in an isolated, pre-apocalyptic United Kingdom, PANIK tells a story about mass hysteria, profit-driven drug companies, and corrupt government. It explores how we are becoming less connected to each other, losing a core part of what it is to be human.

The metonymy Panic is in the subhead of this advertising. Panic is an abstract concept and it has human features in the advertising text. The metaphor the key is used for one of the main characters Rosa. Sometimes the book advertising texts can include antithesis and metonymy at the same time as in the example below:

(28) Incessant Dream by G. J. Maresca 
Some dream of love, wishes, happiness, and even death! But who dreams of living? Meet Rebecca, once a Valley Girl, and now a successful executive who made millions.

The metonymy a Valley Girl, which means 'the poor girl from the 'village' is contrasting with a successful executive, that means the 'rich woman'. There are some examples of a well-known metaphors like the Big Apple, describing New York:

(29) Welcome to New York by Luana Ferraz

When Harry and Alana meet, they recognize each other's scars. They bond over the things they don't say. They find comfort in long silences. But as they learn how to deal with life's plot twists, they find out the Big Apple has its own plans for them.

Their lives are about to get irreversibly intertwined. Do you want to know how?

First of all, welcome to New York!

As stated above repetitions of particular sounds, words, phrases, etc. play the important role in the book advertising text. Some researchers think that the repeated use of synonymous words makes even a prosaic text rhythmic. For example,

(30) The Boy who Dreamt the World by Jentro Punter

Adam is living the dream - literally.... You would think that being in control of your dreams would be fun. But when Nightmares not only roam the dream world but also start chasing him even while he is awake .

Numbers are more memorable and effects on readers' attention that's why they are very often used in books advertising texts, for example,

(31) Balance of the $\mathbf{1 2}$ by Ania Bo The universe was created by 12 energies which turned into the 12 races on earth. Eleven of these races live in secret among mankind, coexisting in precarious harmony and dependent on the Balance between them to keep the universe alive. If one race falls, the universe falls.

It was noticed in the analyzed advertising texts that numbers are widely used in the echo-phrase of the advertising text, and they are an effective means of persuasion, for example,

(32) Hawaiian Masquerade by Rachelle J. Christensen

This novel is Book \#1 in the Burke Billionaire Romance Series and includes a bonus sneak peek of Book \#2! Books can be read in any order. Look for the newest novel, The Refugee's Billionaire! Thank you for reading! Books in the Burke Billionaire Romance Series 
The researchers think that repetitions are the powerful means of speech exposure. Cara-Murza who studied the problem of the impact of the media on people subconsciousness thinks that "repetitions are the main method of the redundancy of stereotypes in consciousness" [6, p. 289] and figures are one of the main objects of the manipulation" [6, p. 451].

At the syntactical level, book advertising can be characterized by the functioning of parallel structures, repetitions of large syntactic structures, intentional omissions of the subject or auxiliary verb, rhetorical questions, inversions, ellipsis, etc. According to Cuddon, parallelism "consists of phrases or sentences of similar construction and meaning placed side by side, balancing each other". For example,

(33) Broken by lies by Rebecca Shea

He changed everything. The way I breathed. The way I loved.

The last two sentences encode the information, which was given by the first sentence and indirectly affect the creation of the book image. Other examples with parallel constructions are the following:

(34) Crossing in time by D. L. Orton The past isn't over, it's an opening. The future isn't hidden, it's a trap.

(35) No Tomorrow by Carian ColeThe people we love are thieves. They steal our hearts. They steal our breath. They steal our sanity .

The example of anaphora, which is "a rhetorical device involving the repetition of a word, or group of words in successive clauses" [15, p.35], for example:

(36) The Three Kitties by Michael Meyer

Love was then. Love is now.

Love is forever.

(37) Bound by Kirsten Weiss

Bound by magic, bound by love, bound by murder....

An epistrophe, that is "a figure of speech in which each sentence or clause ends with the same word" [15, p. 246] is in the next example:

(38) Two Sides of Me by Sarel Nora

A mysterious girl birthed him, but couldn't raise him.

Questions are often used to intrigue readers' attention and make them look for the answers to questions. For example,

(39) Dragon's Treasure by Isadora Montrose

What happens to an arrogant dragon lord when his greatest treasure steals his heart?

(40) Silent Siren by L. B. Carter

Sea level is rising. Who will float? Who will drown? 
(41) Alterations by Jane Suen

Gigi, Ellen, Lilly... three women so desperate to change their lives that they turn to the mysterious Dr. Kite, who offers them an implant that can control their mind. Will Gigi find her true love? Can Ellen's miraculous, sudden weight loss bring her romance and self-respect? Can Lilly put her bitter divorce behind her? They're willing to risk it all to find the happiness they've always searched for.

Questions identify key issues that may be of interest to target auditory. Intentional omissions of the subject or auxiliary verb are used as signals that attract the reader and can hold his attention by stimulating thinking and possibly finding an answer to a question. Such constructions contain relevant enigmas that make it possible to identify the problem, and at the same time give the message to the auditory. For example,

(42) Knightmare Arkanist by Shami Stovall

Magic. Sailing. A murderer among heroes.

(43) Sweet Adventure by Tamie DearenKatie

Carson is afraid of everything. Spiders. Sharks.

As has been shown above, book advertisers bring many linguistic techniques to express and pass on the idea of the advertised book. In this section we dealt with the language means on phonological, morphological, lexical, and syntactical levels in advertising texts.

\section{Onomastics techniques in the books advertising texts}

This part of the paper deals with some points about proper names functioning in the advertising texts. According to List of Key Onomastic Terms, onomastics is the study of proper names in a scholarly way [24, p. 4]. Although the topic of the proper names functioning in the books has been exploited by many researchers, the proper names in online books advertising have not yet been considered. In the present paper, we attempt to show how book advertising texts are becoming catchy with the help of proper names. We suggest that people seem to remember information better with the well-known proper names. Furthermore, because of their cultural background, the readers regard the book advertising text as the fixed unit in which some proper names can be seen in the differing attitudes.

The linguistic phenomenon of proper names is defined as "linguistic expression that uniquely identifies a person, a group of persons, a place, an animal or an object" [24, p.5]. Taking the historical perspective, we have to note that there are different onomastics schools with their own models of onymy, i.e. "the set of proper names within a particular region, 
language, period of time [24, p. 4]. British scientist A. Gardiner $[17$, p. 38-56] has presented the set of proper names and among them, there were personal names, place names, ship names, animals and plants names, names of the months and imaginary names, names of titles, houses names and celestial names. Dutch scholar W. van Langendonck [22, p. 184] classifies proper names into four subclasses. The first, most important class includes prototypical proper names: 1) personal names; 2 ) the names of animals; 3 ) names of places; 4) other names. The second subclass consists of non-prototypical proper names such as names of works of art, books, journals, temporal names, etc. The third and fourth classes are marginal subclasses. The Finnish researchers classified proper names into four groups:1) Personal Names; 2) Animal Names; 3) Nature Names; 4) Culture Names. The third group consists of topographic names, hydronyms, celestial names and the fourth group includes Settlement names, Cultivation names, Transport names, Names of Structures, Names of Artwork, Organisation Names, Product Names [8, p. 26]. And the list of proper names classifications does not stop here.

However, in this paper we will not touch upon the question about the peculiarities of different onomastics systems and suggest dividing the set of proper names in the online book advertising texts into the following groups: 1) personal names (anthroponyms); 2) names of places (toponyms);3) other proper names. The latter group in our research is further subdivided into 1) chrematonyms, i.e. proper names of social events, institutions [24, p. 2]; 2) ideonyms, i.e. proper names of books and newspapers; 4) ethnonyms, i.e. proper names of an ethnic group, or a member of this group [24, p. 2]; 5) chrononyms, i.e. proper names of historically important period, epoch, holiday or certain date [3, p. 2], 6) ergonyms, i.e. proper names of the certain union of people, that is, organization, the party, etc. [3, p. 85]. It must be noted that all groups of proper names are presented in online books advertising with differing frequency but in the present paper, we will analyze only the above-mentioned groups.

Whenever the readers try to understand what the certain book is about, the proper names in book advertising make the book's content more understandable. The function of book advertising texts is the same as that of the other advertising: to make the customer buy the advertised thing. But in the case of book advertising texts, they have many proper names. Let's consider the examples:

(44) 1777 - Danbury on Fire! by M. H. B. Hughes 
1777 - Danbury on Fire! is an all-ages historical novel of the American Revolution. From dinner party to disaster, a boy threads his way through the British raid on a small-town Connecticut rebel commissary. Young Joe Hamilton's prominent family has shattered over the rebellion, but the redcoat invasion forces everyone to abandon core beliefs and face the consequences of their own acts. Whether you wonder about the lives of your ancestors or want to relive classics like Johnny Tremaine, this book surrounds fact with Joe's caustic commentary.

The main function of both the anthroponyms and the toponyms is informative. When reading the text we may pay attention to such proper names as anthroponyms Joe Hamilton, and Johnny Tremaine, toponyms Danbury and Connecticut, the chrononym the American Revolution. The toponyms are linked with the history of the USA. People who are interested in the history know that the $21^{\text {st }}$ of April 1777 was the day when the British troops under the command of General William Tryon attacked the town of Danbury in Connecticut. Such reminders of the American Revolution in historical fiction help to find out more about the World history.

It must be mentioned that three groups of anthroponyms were found in the studied material: 1) first names, 2) surnames, 3) nicknames. First names and surnames and are the most frequent groups of anthroponyms used in the book advertising text. They are used in all structural components of books advertising, for example, in the main text,

(45) New Orleans Mourning by Julie Smith

Winner of the 1991 Edgar Allan Poe Award for best novel and the FIRST mystery in the highly acclaimed Skip Langdon series, New Orleans Mourning falls deliciously between the psychological suspense of Laura Lippman and the delicate drama of Tennessee Williams. "Smith is a gifted writer." -Washington Post Book World Fans of Ace Atkins, Tana French, Sue Grafton, and Marcia Muller will love Skip Langdon's pluck and charm MURDER, MARDI GRAS--AND MORE SECRETS THAN BEADS.

People seem to pay attention to anthroponyms better than any other words in the advertising text because personal names belong to such a lexical section, which is closely connected with the life of man. Besides personal names are an integral element of the advertising language, and, in addition, they have a huge linguistic and pragmatic potential. It is worth mentioning, that anthroponyms can be used both in the main advertising text and in the echo-phrase in order to increase impact on the readers, for example, 
(46) Catching Sin by J. Saman

\section{Isabe}

I was under the devil's thumb with no end in sight.

A play thing. A toy. A treasure easily forgotten.

Until Maddox Sinclair stepped into my club and made me promises even my tattered heart couldn't refuse.

\section{Maddox}

I met her in hell. In the last place you should ever meet anyone... a strip club. It was a typical Las Vegas night. Until Isabel Bogart stepped on that stage.

She's like a statue in a museum. Priceless, irrevocably damaged and untouchable. A mobster's girl. They did and now... Now there's no going back until I save her.

Grab your copy of CATCHING SIN today and get lost in Maddox and Isabel's irresistible world of sin.

The function of both the anthroponyms and the toponyms is informative. Sometimes the advertising text include the nicknames of the famous historical persons in order to direct readers' attention to the idea and the plot of the advertised book, for example the proper name Dracula in the next example, draws the attention of those who are interested in horror stories.

(47) The Tegen cave by Inge-Lisa Goss

Goss immerses the reader in a gripping tale in which spiders are trained to kill. To some, the story may seem far-fetched, and cult members eating the flesh of cadavers may seem abhorrent, but Dracula set that table long ago. Tegen Cave is sure to thrill anyone predisposed to the fantasy genre.

The anthroponym Dracula was for centuries known as the nickname of Vlad III, one of the most important rulers in Wallachian history.

In the pioneering study devoted to functions of advertising names, Kryukova [21, p. 2] demonstrates that, firstly, the proper names of a group of people organized according to some business interest, such as a union, a society, an enterprise, or a sector, secondly, proper names of a trademark, and thirdly, proper names of printed media including magazines and newspapers, are considered as advertising names. These advertising names become "a means of direct or figurative characterization in contemporary journalistic or literary texts" [21, p. 10]. However, to our mind, books advertising texts have special set of proper names, and mostly all kinds of proper names both can be used as figurative means of language and have pragmatic effects. The best examples to illustrate this is the following example:

(48) Hollow-Point Diplomacy by R.H. Johnson 
Russia and Iran have joined forces in an effort to seize control of Eastern Europe and the Middle East, and only one man is capable of making sure that doesn't happen. Travis Delta is the top gun at Snakeriver, a shadowy private company that handles assignments the U.S. government is prohibited from managing on its own. Years of battlefield experience have taught him that a skillfully placed hollow-point bullet often accomplishes what normal diplomatic channels cannot, and he has no problem squeezing the trigger when words fail.

$\boldsymbol{R}$.H. Johnson's tenth novel, geopolitical fiction that reads like front-page news, takes you on a wild ride from D.C. to Tehran, Riyadh, Jerusalem, Tel Aviv, Moscow, Beijing, and Berlin as Delta declares war on evil.

You won't want to put this one down.

The use of toponyms Russia, Iran Tehran, Riyadh, Jerusalem, Tel Aviv, Moscow, Beijing, and Berlin, ergonyms Travis Delta, and the U.S. government direct the readers' attention to the main characters of the advertised book. It must be noted that the most encountered were anthroponyms and toponyms in the analyzed advertising texts. Toponyms in the above advertising text can be attributed to the keywords of the text, which could represent, to some extent, the idea of the book. Two groups of toponyms were the most frequently found in the studied material: 1) choronyms; 2) oikonyms. The term choronym is defined as "proper name of a larger geographical or administrative unit of land" [24, p. 2] and the term oikonym or settlement name is defined as "proper name of all kinds of human settlement (cities, towns, villages, hamlets, farms, ranches, houses, etc." [24, p. 5]. The choronyms Russia, Iran Eastern Europe, Middle East and oikonyms Tehran, Riyadh, Jerusalem, Tel Aviv, Moscow, Beijing, and Berlin as Delta were used in the above mentioned advertising text. The ideonym Romeo and Juliet functions as the code of the next advertised book.

(49) Sewing Can Be Dangerous and Other Small Threads by S.R. Mallery

These eleven short stories range from drug traffickers using handwoven wallets, to a U.S. slave sewing freedom codes into her quilts; from a cruise ship murder mystery with a quilt instructor and a NYPD police detective, to a couple hiding Christian passports into a comforter in Nazi Germany; from an old Salem Witchcraft wedding quilt curse to a young seamstress in the infamous Triangle Shirtwaist Factory fire; from a 1980's Romeo and Juliet romance between a Wall Street financial 'star' and an eclectic fiber artist, to a Haight-Ashbury love affair between a professor and a macramé artist gone horribly wrong, just to name a few. 
The ideonyms in the form of newspapers titles are often used in the readers' reviews and commentaries in order to create the impression of wide audience of the advertised book readers, for example,

(50) Louisiana Bigshot by Julie Smith

"Smith has perfect pitch. It's great to hear her again ... a multilayered mystery and a quirky, believable heroine." Booklist

"The quirky pleasure of watching the Baroness strut her stuff is worth the price of admission.Houston Chronicle. "Louisiana Bigshot is a character-driven tale with plenty of action, suspense, and steamy southern atmosphere... It's an exhilarating romp that will have you cheering forTalba. The Mystery Review. "Wallis is fine fun to get to know... a consistently interesting and likable woman of depth and complexity. The Washington Post. "Smith's new series is a whole other kettle of crayfish: wilder and funnier. Chicago Tribune.

To our mind, the specification of book advertising text is based on three main components. First, it reflects the attitude of modern society to the problem of reading. Secondly, books as a matter of advertising differ from the goods of consumer goods, because they are related to the nonmaterial, which have always been very important for people. Thirdly, an important role is played by the destination factor, namely, the target audience. The book about the Second World War and the participation of Americans in it will be interested for those who like reading historical books like in the following example:

(51) The Things our Fathers saw by Matthew Rozell

"For all of us to be free, a few of us must be brave, and that is the history of America". Read how a generation of young Americans saved the world. Because dying for freedom isn't the worst that could happen. Being forgotten is. From the deserts of North Africa to the mountains of Italy, the men and women veterans of the Italian campaign open up about a war that was so brutal, news of it was downplayed at home. By the end of 2018, fewer than 400,000 of our WW II veterans will still be with us, out of the over 16 million who put on a uniform. But why is it that today, nobody seems to know these stories?

Maybe our veterans did not volunteer to tell us; maybe we were too busy with our own lives to ask.

Although all subclasses of proper names can be used in the advertising texts, some of them are used less frequently than others, for example, ethnonyms and chrononyms like in the above-mentioned book: Americans and WW II. 
Chrematonyms are often used at the beginning and at the end of the advertising text and they usually include the names of awards, for example,

(52) Solitude: Dimension by Dean M. Cole (Author)

Winner 2018 Listeners Choice: Best Sci-Fi

Complete Trilogy Now Available

The Martian meets Gravity when Earth's last man, Army Captain Vaughn Singleton, discovers that the last woman is stranded alone aboard the International Space Station. Commander Angela Brown could reverse the event that swept humanity from Earth's surface ... if only she could get there. If you like action-packed, page-turning novels, you'll love the electrifying action in this award-winning, apocalyptic thriller. Can Humanity's Last Two Unite?Grab your copy and start reading today!

(53)The Fatness by Mark A. Rayner

Keelan Cavanaugh is fat. That's why the government put him in prison. They placed him in a Calorie Reduction Centre (CRC), where trained staff work to help him and many others slim down. Can he succeed, and will the CRC-crossed lovers ever sit at love's banquet together?

From award-winning author Mark A. Rayner, The Fatness is a contemporary satire of socialism, capitalism, and the so-called "obesity epidemic". This is Catch-22 for a new generation, with a distinctly tender undertone, even as it mercilessly spoofs the establishment. Winner of Two Literary Awards for Humor!

IPBA Benjamin Franklin Award for Best Humor (silver), 2018.

Although we may assume that all subclasses can be used in the book advertising texts, some of them are used less frequently than others. It depends on the topic of the books and the target audience as well, for example, there were some theonyms, like God, in the analyzed advertising texts:

(54) Becoming me by Staci Stallings

Is there something greater than we know? Can we, through the talents God has given us, tap into a well-spring our mortal senses do not see? If so, how do we encourage each other to find that deeper "something," or do we rationalize each other out of even searching for it?"Becoming Me" begins The Imagination Series by USA Today Best-Selling Christian author Staci Stallings.

All in all, the aim of using proper names in the advertising texts is not only to inform readers about the main characters of the book but they could have a pragmatic potential as well. Proper names functioning in the book advertising help to implement the functions of informing and persuading. 


\section{Conclusions}

Thus, in the 21-st century, it was created fundamentally new opportunities for book advertising except for printed forms. The Internet reality creates its own space of culture, changing people's stereotypes of thinking and behavior. This paper researched the linguistic and onomastics means of persuasion in the books advertising texts on the Internet. The paper focuses on the proper names functioning and shows 1) lexical features of the book advertising and 2) how various types of proper names help to create the whole tissue of advertising.

The expressivity of the text is determined by the use of various means of the language. It has been shown in this paper the different language techniques on the phono-graphical, morphological, lexical, syntactical levels. Proper names with a high suggestive value make an advertising message suggestive, increasing its efficiency, and also forming the image of the advertised book. Generally speaking, book advertising goes beyond the economic sphere and becomes a phenomenon of human culture. In our time books advertising performs both the functions of art and propaganda. As a result of the investigation, the peculiar advertising techniques in the online English book advertising texts were studied. Summarizing the above-mentioned, we can emphasize that for the first time the analysis of onyms in online book advertising texts in English was carried out. After analyzing the proper names of the advertising texts, it was concluded that the onymy in the studied material is formed mainly with the help of toponyms, anthroponyms, ergonyms, ideonyms, chrematonyms, ethnonyms and chrononyms. An analysis of the material showed that anthroponyms have the highest frequency of use compared with other categories and account for $43 \%$. It has been established that toponyms make $29 \%$, the other subclasses of proper names make $28 \%$. It has been proven that proper names are an additional source of expressiveness; they contribute to the impact of advertising on the readers'. The practical value of the work lies in the fact that the analysis of onyms in books advertising texts opens up the prospects for further researches, which may be associated with the identification of differential features of onyms in advertising texts with various advertising objects, and it may be connected with the national identity of advertising texts in different languages.

\section{References:}

1. Айзенштейн К. А. Как рекламировать с успехом. Настольное руководство для деловых людей с образцами умелых и оправдавшихся. СПб.: Фортуна для всех, 1902. 110 с. 
2. Булик Ю. В. Рекламний текст в параметрах аксіологічної прагмалінгвістики: автореф. дис... канд. филол. наук: 10.02.02. Харків, 2009. 20 с.

3. Бучко Д. Г, Ткачова, Н. В. Словник української ономастичної термінології. Харків: Ранок-НТ, 2012. 256 с.

4. Грушевська Ю. А. Власні назви в російському рекламному тексті: лінгвістичний і функціональний аспекти: автореф. дис.... канд. филол. наук: 10.02.02. Дніпропетровськ, 2005.18 с.

5.Зирка В. В. Языковая парадигма манипулятивной игры в рекламе: автореф. дис.... док. филол. наук: 10.02.02. Днепропетровск, 2005. 414 c.

6. Кара-Мурза С. Г. Манипуляция сознанием. Москва: Эксмо,2003.832 с.

7. Рюмшина, Л.И. Манипулятивные приёмы в рекламе. Ростов н/Д: Март, 2004. 240 с.

8. Ainiala, Terhi Saarelma, Minna, and Paula, Sjöblom. Names in Focus: An Introduction to Finnish Onomastics, L. Pearl (trans.). Helsinki: Finnish Literature Society, 2012. 290 p.

9. Arens F. William. Contemporary Advertising (7 ed.). Boston: The McGraw-Hill, 1999. 569 p.

10. Beasley Ron and Danesi Marcel. Persuasive Signs: The Semiotics of Advertising. Berlin. New York: Mouton de Gruyter, 2010.193 p.

11. Blakeman Robyn.The Bare Bones of Advertising Print Design. Lanham. Boulder.New York. Toronto. Oxford: Rowman \& Littlefield Publishers, 2004.184 p.

12. Brewster Arthur Judson, and Palmer, Herbert Hall (2001). Introduction to Advertising. Honolulu Havaii: University Press of the Pacific, 2001. 392 p.

13. Burton Philip Ward. Advertising copywriting. Lincolnwood, Illinois: NTC Business Books, 1999. 349 p.

14. Copley Paul . Marketing Communications Management: concepts and theories, cases and practices. Oxford: Elsevier ButterworthHeinemann, $2004.457 \mathrm{p}$.

15. Cuddon J. A. Bowden (1998). Dictionary of Literary Terms and Literary Theory. London: Penguin Books,1998. $114 \mathrm{p}$.

16. Frith Katherine Toland (1997). Undressing the Ad: Reading Culture in Advertising. New York: Peter Lang, 1997. 250 p.

17. Gardiner Alan. The Theory of Proper Names: A Controversial Essay. London: Oxford University Press, 1957. 79 p. 
18. Goddard Angela . The Language of Advertising: Written Texts. London and New York: Routledge, 2002.134 p.

19. Janoschka Anja. Web Advertising: New Forms of Communication on the Internet. Amsterdam/ Philadelphia, 2004. 227 p.

20. Jefkins Frank. Advertising. Harlow: Pearson Education Limited, 2000. $374 \mathrm{p}$.

21. Kryukova Irina. Functions of Advertising Names in Different Types of Russian Texts. Onomastics in Contemporary Public Space. Newcastle upon Tyne: Cambridge Scholars Publishing: 2013. P. 2-10.

22. Langendonck Willy van. Theory and Typology of Proper Names. Berlin: Mouton de Gruyter, 2007.378 p.

23.Lee Monle and Johnson Carla. Principles of Advertising: A Global Perspective. Binghampton: The Haworth Press, 2005. 454 p.

24. List of Key Onomastic Terms. Available from https://icosweb.net/wp/wp-content/uploads/2019/05/ICOS-Termsen.pdf (Дата звернення 15.11.2021).

25. O'Shanghnessy Nicholas Jackson. Persuasion in Advertising. London: Routledge, 2004. 220 p.

26. Perreault William. D., McCarthy Jerome. E. Basic Marketing: a global managerial approach . New York: Irwin McGraw - Hill, 1996. 829 p.

27. Quinn Edward. A Dictionary of Literary and thematic Terms. New York: Facts on File, 2006. 474 p.

28. Rorty James. Our Master's Voice: Advertising. New York: The John Day Company, 1934. 424 p.

29. Shohamy Elana and Gorter, Durk . Linguistic Landscape: Expanding the Scenery. New York: Routledge, 2009. 352 p.

30. Sivulka Juliann. Soap, Sex, and Cigarettes: A Cultural History of American Advertising. Boston: Waseda University, 2011. 450 p.

31. Sumner Guy Lynn. How I Learned the Secrets of Success in Advertising. New York: Prentice-Hall, 1952. 450 p.

32.Tanaka Keiko. Advertising Language: a Pragmatic Approach to Advertisements in Britain and Japan. London: Routledge, 1994. 148 p.

33.Tungate Mark. Ad Land: A Global History of Advertising. London and Philadelphia:Kogan Page Publishers, 2007. 278 p. 